cuddled him later on. The infant is therefore presumed to have been infected in utero.

Although the second infant was home for seven days before the mother's diagnosis, it is unlikely that this infant was infected postnatally, as this period was considerably less than the six to eight weeks required by the tubercle bacilli to multiply.

The ear would be a most unusual site for a primary infection. It is speculated that transmission occurred by infected amniotic fluid being lodged in the fetal auditory canal, either in utero or during birth. After birth, the auditory canal provides a moist, relatively well oxygenated environment suitable for growth of tubercle bacilli. The delay in clinical presentation accords well with the time required by the organism to multiply. The absence of systemic manifestations make infection from transplacental spread, or by aspiration of infected liquor, unlikely.

We thank Dr NT von Diggelen for interpretation of the histology and photographs, and Drs JD Kane-Berman (Groote Schuur Hospital) and Frazer-Ross (Brooklyn Chest Hospital) for permission to publish.

\section{References}

${ }^{1}$ Hageman J, Shulman S, Schreiber M, Luck S, Yogev R. Congenital tuberculosis: critical reappraisal of clinical findings and diagnostic procedures. Pediatrics 1980;66:980-4.

2 Nemir RL, O'Hare D. Congenital tuberculosis: review and diagnostic guidelines. Am J Dis Child 1985;139:284-7.

${ }^{3}$ Huber GL. In: Remington JS, Klein JO, eds. Infectious diseases of the fetus and newborn infant. 2nd ed. Philadelphia: WB Saunders, 1983.

${ }^{4}$ MacAdam AM, Rubio T. Tuberculous otomastoiditis in children. Am J Dis Child 1977;131:152-6.

${ }^{5}$ Sellars SL, Seid AB. Aural tuberculosis in childhood. $S$ Afr Med J 1973;47:216-8.

${ }^{6}$ Bate TWP, Sinclair RE, Robinson MJ. Neonatal tuberculosis. Arch Dis Child 1986;61:512-4.

Correspondence to Dr RC Naranbhai, Department of Paediatrics, University of Cape Town, Observatory, 7925, South Africa.

Accepted 24 October 1988

\title{
Munchausen's syndrome in a 4 year old
}

\section{R D CROFT AND M JERVIS}

Department of Paediatrics, Barnet General Hospital

SUMMARY From the age of 4 a boy repeatedly feigned epileptic fits. He later admitted that his mother had taught him that he was epileptic and had trained him to behave like that.

Munchausen's syndrome by proxy is the fabrication by a mother of false symptoms and signs of illness in her child. The commonest form of this syndrome is fictitious epilepsy. We describe a case where a mother not only fabricated a false history of epilepsy in her 4 year old son, but also trained him to feign epileptic fits.

\section{Case report}

A 2 year old boy was referred to the outpatient department by his family doctor because his mother had reported that he had episodes of cyanosis. No abnormality was found. He was again referred at the age of 3 because of episodes of shaking and unconsciousness. The electroencephalogram was normal, and no firm diagnosis was made. His mother continued to report that he had fits and when he was 4 years old a diagnosis of epilepsy was made and he was treated with sodium valproate. Three months later he was admitted to hospital because of fits, and on several occasions was observed lying apparently unconscious and trembling. He was, however, easily roused by the mention of his favourite food, and it was obvious that he was feigning the fits. The diagnosis of epilepsy was withdrawn and treatment was stopped.

His mother continued to claim that he was having fits, and so they were both referred for psychiatric help. Despite this she repeatedly brought him to hospital claiming he had been having fits. On one occasion he was brought to the clinic in a pushchair, wearing nappies and a crash helmet, and being fed from a baby's bottle. When he was 5 he was admitted to hospital during an apparent fit, and was given intravenous diazepam by a house officer who did not know him. During this admission he feigned further fits, and pretended to have a paralysed arm for two days. He also stated that he was epileptic. Two weeks later he was again admitted to hospital during an apparent fit but the next day was able to give a clear account of all that had occurred at that time.

At a case conference the family doctor told us that the boy had been brought to the surgery 130 times. 
This was in addition to 35 visits to the hospital accident and emergency department. During this conference, the head teacher of the boy's school recounted conversations between herself and the boy that she had recorded on tape. He had described how his mother had trained him to simulate epileptic fits by falling off his chair, shivering, and flickering his eyes. He had been seen to act in this way at school, and had told his head teacher that he had done so 'because mummy said I should'. He also told her that his mother sometimes rewarded him with food and drink when he had acted in this manner. The head teacher said that for a child of his age his ability to express himself was exceptional, and that his statements were clear and unambiguous.

The decision of the case conference was that an application should be made to the Court for the boy to be taken into care. Five months after being received into care, the boy had had no further fits. He told our child psychiatrist that he no longer had epilepsy.

\section{Discussion}

We have described a boy whose mother not only claimed that he was epileptic, but also trained him to feign epileptic fits from the age of $4 \frac{1}{2}$.

Fictitious epilepsy is the commonest form of Munchausen's syndrome by proxy. ${ }^{1}$ The parent, invariably the mother, attempts to convince doctors that her child has epilepsy. The commonest strategy is simply to give an untruthful history. A second less common strategy is to induce fits in the child, usually by smothering. ${ }^{2}$ This sometimes occurs in hospital, and has been detected by video surveillance. ${ }^{3}$ This case shows that a third strategy may be adopted: to train the child to feign epileptic fits. This strategy has not previously been reported to our knowledge.
This case has many typical features of Munchausen's syndrome by proxy. There are also some features of classical Munchausen's syndrome: the child himself feigned illness, and claimed to be suffering from this illness, admittedly because his mother had trained him to do so. Munchausen's syndrome has not previously been described in a child of this age. According to Meadow, in cases of Munchausen's syndrome by proxy it is quite common to find that as the child reaches school age complicity develops between the mother and child, and that 'the fabrication becomes a joint effort'. Later, older children may be 'programmed into illness behaviour'. We can find no previous report of a child having been successfully 'programmed into illness behaviour' at the age of 4 .

The diagnosis of fictitious epilepsy may be difficult and is often delayed. In the series reported by Meadow the median length of the false illness was 3.9 years. Many of these children may have been too young to give a history themselves. Nevertheless our case shows that in fictitious epilepsy, as in other forms of child abuse, an interview with the child can yield important information.

We thank Dr K Norton for permission to report one of his patients.

\section{References}

1 Meadow R. Fictitious epilepsy. Lancet 1984;ii:25-8.

${ }^{2}$ Meadow R. Factitious illness-the hinterland of child abusc. Recent advances in paediatrics No 7. London: Churchill Livingstone, 1984

3 Southall DP, Stebbens VA, Rees SV, Lang MH, Warner JO, Shinebourne EA. Apnocic episodes induced by smothering: two cases identified by covert video surveillance. Br Med J 1987;294: $1637-41$.

Correspondence and requests for reprints to Dr RD Croft, Chailey Heritage Hospital, North Chailey, nr Lewes, East Sussex BN8 4EF.

Accepted 13 December 1988 